\title{
Nuclear Factor 1 A-Type
}

National Cancer Institute

\section{Source}

National Cancer Institute. Nuclear Factor 1 A-Type. NCI Thesaurus. Code C38400.

Nuclear factor 1 A-type (509 aa, $\sim 56$ kDa) is encoded by the human NFIA gene. This protein plays a role in the regulation of both gene replication and transcription. 